\title{
SINERGITAS FILSAFAT DAN AGAMA BAGI MASYARAKAT DI ERA KONTEMPORER
}

\author{
Oleh: Mat Jalil
}

\begin{abstract}
ABSTRAK
Sinergitas filsafat dan agama dua hal prinsip hidup setiap orang untuk bersungguh sunguh Berfilsafat bukanlah merupakan pekerjaan yang setiap saat dapat saja dimulai dan yang semauanya dapat dihentikan,berfilsafat lebih merupakan suatu mentalitas berpikir suatu sikap dan penyesuaian pribadi yang dibiasakan secara perlahan-lahan dan dengan susah payah sehingga oleh karena itu menjadi milik kita secara tetap,belajar berfilsafat belajar membuka diri dan bersedia untuk itu (membuka diri), sedamgkanberagama atau berkeyakinan adalah suatu fitrah bagi manusia. Hal ini bertolak dari kesadaran manusia akan ketidak-berdayaan dirinya dan adanya sesuatu yang transenden yang patut diunggulkan. Agama, sebagai pegangan hidup manusia, tentu tidak hanya berhenti sebagai pemikiran ideal belaka, melainkan, seiring perjalanan waktu, harus diterjemahkan dalam bingkai realitas kehidupan manusia. Agama kemudian mencari posisinya yang apresiatif terhadap realitas, namun tanpa mereduksi prinsip-prinsipnya
\end{abstract}

Kata kunci: mentalitas berpikir dan penyesuan diri

\section{PENDAHULUAN}

Setiap orang memiliki filsafat walaupun ia mungkin tidak sadar akan hal tersebut, semua orang memiliki ide-ide tentang benda, sejarah, kehidupan, mati, Tuhan, benar atau salah, keindahan semua itu berkembang menjadi pengertian dan pengalaman hidup. Filsafat adalah pengetahuan yang diperoleh dengan cara berpikir logis tentang objek yang abstrak, yang kebenarannya dipertagungjawabkan secara logis. Manusia memikirkan segala sesuatu secara sistimatis, radikal dan universal, sistem ini membentuk pengetahuan yang diistilahkan dengan pengetahuan filsafat. Pengetahuan filsafat menjawab persoalan-persoalan yang tidak terjawab oleh pengetahuan indra dan pengetahuan ilmu, Obyek material filsafat yaitu semua yang ada dan yang mungkin ada, yang diselidiki bagian yang abstrak tentang objek. Filsafat dalam usahanya mencari jawaban-jawaban dengan berdasarkan kekuatan pikiran manusia bukan berdasarkan wahyu. Filsafat adalah ilmu pengetahuan mengenai segala sesuatu dengan memandang sebab-sebab yang terdalam.

Filsafat dan agama merupakan hal yang penting bukan hal yang remeh, filsafat dan agama menyangkut soal hidup dan matinya seseorang, filsafat sebagai landasan hidup dan agama sebagai pegangan hidup, maka sinergitasnya sangat dibutuhkan, manusia akan mempertahankan philoshifi kehidupanya, karena philosofi kehidupan ini menyangkut soal prinsip kehidupan dan prinsip kehidupan merupakan suatu eksistensi kehidupan, begitu juga 
dengan agama sebagai tuntunan kehidupan yang membimbing arah manusia dalam menjalani kehidupan. Dua orang filosuf Plato dan Aristoteles yang tidak beragama, atheis tetapi keduanya menyakini merasakan dan mengakui bahwa di atas kekuasaan alam ini ada kekuasaan yang maha tinggi itulah Tuhan yang maha Esa.

Masyarakat di era kontemporer berpikirnya selalu saja pragmatis, kepragmatisanya ditujukan dalam setiap tindakan semua prilakunya harus menghasilkan sesuatu. Pragmatisme dalam bahasa Yunani berarti tindakan dan perbuatan. Pragmatisme sebagaimana yang di ketahui tindakan apa akibatnya, apakah dapat dipahami secara praktis atau tidak. Seseorang akan mendapat pengertian tentang objek itu, kemudian konsep seseorang tentang akibat, itulah keseluruhan konsep objek itu.Pragmatisme adalah realitas sebagai mana yang diketahui ${ }^{1}$. Kepercayaan juga pragmatisme, kepercayaan bukanlah sekedar aturan-aturan bertindak atau idea untuk siap bertindak, kepercayaan merupakan sesuatu yang berguna di dalam membuat sesuatu, dalam membuat sesuatu pasti benar.Ada kasus-kasus kenyataan yang tidak jelas kecuali bila ada keyakinan pendahuluan yang menyertai pemunculannya. Moral dan agama merupakan contoh yang tidak dapat dipecahkan semata-mata secara intelektual atau teoritis, tetapi dapat dipecahkan secara pragmatis,

Agama dan speritual bekerja dalam kehidupan manusia tidak secara statis dan bukan sebagai prinsip abstrak, melainkan fungsional dan dinamis. Pragmatisme dapat sekaligus religius dan faktual, karena agama di interprestasikan secara volutaris, sebagai tujuan atau aspirasi yang secara nyata beroperasi dan memperkaya kehidupan, itu bukan pesimistis melainkan optimistis. Pragmatisme tidak menjamin bahwa masa depan seseorang akan lebih baik dari pada masa lalu, tetapi ia memberikan harapan dengan usaha dan keyakinan bahwa masa depan itu akan lebih baik. Pragmatisme dapat digunakan sebagai methode mengatasi persoalan dengan cara menemukan akibat-akibat praktis yang muncul dari penerapan ide. Bila ditanya mana yang benar materialisme atau speritualisme, cukup dijawab akibat-akibat praktis apa yang ditimbulkan oleh kedua aliran itu, persoalan yang ada diantara keduaduanya memang tidak pernah dapat diselesaikan.

Agamamerupakan perasaan, tindakan dan pengalaman manusia individual didalam kesunyianya. Persoalan agama tetap pada keyakinan kepada sesuatu yang Tinggi. Untuk menafsirkan pengalaman beragama seseorang dengan melihat sebabnya terjadi, harus melihatt hasil pengalaman lebih jauh, Doa misalnya harus dilihat bukan pada terkabul atau

${ }^{1}$ Tafsir, Filsafat Umum Akal dan Hati Sejak Thales Sampai Capra, Penerbit RosadaBandung, 2013, hal190 
tidaknya doa, melainkan pada hubungan beban mental seseorang. Pengalaman beragama berguna bagi manusia tetapi belum tentu bagi semua orang, kebenaran agama subjektif, pengalaman tidak dapat membantu menjelaskan realitas Ilahiyah atau realitas agama.

Orang tidak mau menerima agama karena secara ilmiah tidak terbukti, kebenaran agama adalah kebanaran yang belum selesai, tetapi dalam sains pun sama kebenaran sains belum selesai.kebenaran agama kurang mencukupi dilihat dari sudut sains, tetapi secara pragmatis agama berguna bagi manusia. Kehidupan beragama erat kaitanya dengan metafisika. metafisika yang mendasarkan diri pada teori-teori pengetahuan, yaitu metafisika yang mau mengganti pandanganya yang statis tentang perubahan didunia ini, psikologi dapat membantu menenangkan apa berfikir, persepsi, kesadaran, konsep dan sebagainya. teori pengetahuan harus dihubungkan dengan psikologi dan menggunakan penemuan-penemuanya.

\section{FILSAFAT}

Apakah filsafat dan mengapa orang mengejarnya, inilah pertanyaan pertama yang timbul dan harus dijawab, sebab apabila hendak berfilsafat harus mengerti dulu apakah yang harus dilakukan, sebab tampa pengertian tentang apa yang akan dilakukan orang tidak dapat berbuat, pengertian filsafat dalam arti yang sederhana sering berhadapan dengan peristiwa sehari-hari.

Peristiwa-peristiwa dalam hidup keseharian sering ditanggapi sebagai suatu hal yang biasa yang tidak menimbulkan rasa heran atau kagum. Berulangkali seseorang menyaksikan bunga pohon mangga berguguran sebelum menghasilkan buahnya,sampai pada suatu saat sekuntum bunga jatuh melayang menimbulkan rasa heran dalam hati. Apa artinya gejala ini? apa maksudnya? pohon mangga sebelum berbuah menaburkan bunga-bunganya ? Adakah semuanya ini terjadi dalam rangka yang lebih luas,seseorang menemukan mawas diri dalam bunga yang berguguran, seseorang menemukan jejak perjalanan dirinya sendiri, manusia melihat perjalanan dirinya yang tidak menentu, termenung, saat itulah, seseorang mulai belajar menjadi filsuf.

Kata filsafat atau falsafah merupakan ucapan Arab yang ditransper dari bahasa YunaniPhiloshopia, suatu kata majemuk dari dua suku kata "Philo dan Shopia. Philo berarti Cinta dan shopia berarti hikmah kebijaksanaan (Love of Windons) atau kebenaran, jadi 
philosopiacinta hikmah atau cinta kebenaran ${ }^{2}$. Kata hikmah di sini dapat berarti kebijaksanaan, ilmu dan sebagainya tetapi dalam bahasa Indonesia lebih tepat diartikan dengan rahasia.

Para ahli ada yang mengatakan bahwa shophia mengandung arti yang lebih luas dari kebijaksanaan arti shophia mengandung makna pengetahuan yang luas (wide knowledge) kebijaksanaan (intlectual virtues), pertimbangan yang sehat (sound judgement) kecerdikan dalam memutuskan hal-hal yang praktis. Istilah filsafat awalnya merupakan suatu istilah yang secara umum digunakan untuk menyebutkan usaha kearah keutamaan mental.

Menurut tradisi Sucrateslah yang pertama-tama menyebut diri Philoshopia sebagai protes terhadap kaum shopist, kaum terpelajar pada waktu itu yang menamakan dirinya kebijaksanaan, padahal kebijaksanan mereka itu hanya semu ${ }^{3}$ Sucrates lebih suka menyebut dirinya pencipta kebijaksanaan artinya orang yang ingin mempunyai pengetahuan yang luhur, mengingat keluhuran pengetahuan yang dikerjakanya, maka Sucrates tidak mau berkata bahwa dirinya telah memiliki pengetahuan.

Filsafat dapat berarti cinta akan kebijaksanaan, persoalan berikut apakah kebijaksanaan, dan kebijaksanaan mempunyai kaitan dengan mengerti (know) namun tidak semua mengerti berarti kebijaksanaan, definisi kebijaksanaan setiap manusia mempunyai perbedaan, kebijaksanaan disini merupakan pengetahuan dalam bentuknya yang paling tinggi, yakni pengetahuan mengatasi ilmu-ilmu lain, sifatnya lebih sistematis, mendalam, radikal, universal dan lebih sesuai dengan kodrat manusia.

Dilihat dari segi pengetahuan praktis filsafat berarti alam berpikir atau alam pikiran, berfilsafat berarti berpikir secara mendalam dan dengan sungguh-sungguh untuk mendapat ilmu pengetahuan ${ }^{4}$. Filsafat adalah pengetahuan dimana filsup menyusun buah pikirannya membentuk suatu sistem pengetahuan yang disebut sebagai filsuf . Filsafat merupakan usaha manusia dengan akalnya untuk memperoleh suatupandangan dunia dan hidup yang memuaskan diri ${ }^{5}$

Filsafat akan lebih mudah dipahami melalui pendekatan secara oprasional, berfilsafat dapat mengandung arti melakukan aktifitas filsafat, dengan demikian akan menggunakan seperangkat metode-metode filsafat dan sekaligus mempunyai filsafat. Jadi manusia mempunyai problema khas yang diusahakan untuk dipecahkan dengan berpikir yang khas

\footnotetext{
${ }^{2}$ Hanafi, Ihtisar Sejarah Filsafat Barat, Penerbit Putaka AlHusna Jakarta, 1981, hal 9

${ }^{3}$ Burhanuddin Salam, 1995, Pengantar Filsafat, Penerbit Bumi Angkasa Jakarta 1995, hal 46

${ }^{4}$ Bakry, Hasbullah, Sistematik Filsafat, Penerbit Widjaya Jakarta 1970, hal, 7

${ }^{5}$ Hadiwiyono, Sari Sejarah Fisafat Barat 1, Penerbit Kanisius,Yoogyakarta, 1988, hal 8
} 
sehingga menghasilkan kesimpulan serta pemecahan persoalan tersebut dalam suatu himpunan pengetahuan yang khas pula. Tetapi himpunan pengetahuan yang khas ini kemudian berfungsi ganda bagi subjek (manusia) yang berfilsafat.

Himpunan pengetahuan merupakan umpan balik dalam rangka menghadapi dan mengusahakan pemecahan problema yang semula dihadapi itu agar dapat diselesaikan dengan memuaskan. Himpunan pengetahuan khas ini ternyata juga dapat dan selalu dipergunakan sebagai masukan (input) baru yang dipakai untuk titik tolak dan kerangka acuan dalam menghadapi dan mengusahakan pemecahan problema yang dihadapi oleh subjek, dari persoalan tersebut dapat berupa persoalan hidup sehari-hari, persoalan marol, politik, ekonomi dan sosial kemasyarakatan.

Filsafat menyelidiki segala sesuatu dengan mendalam, mengenai ketuhanan, alam semesta dan manusia sehingga dapat menghasilkan pengetahuan tentang bagaimana sikap manusia itu seharusnya setelah mencapai penegtahuan itu. Filsafat ilmu yang merupakan dasar (asas) dari segala ilmu yang masih bersifat umum (global) tentang hakikat dan segala kenyataan di alam ini, hingga kepada sesuatu yang tidak dapat diteliti tetapi dapat diperiksa

Dasar dari segala ilmu yang masih bersifat umum ini memiliki karakteristik yang merupakan ciri khas atau bentuk tabiat, segala sesuatu karakter dan ciri sebagai spikasi dari sesuatu ilmu yang dikaji dan menunjukkan perbedaan satu kajian ilmu yang satu dengan yang lainya. Karakteristik pemikian filsafat, bersifat menyeluruh, mendasar dan spikulatif

Karakteristik pemikiran filsafat yang pertama adalah sifatnya yang menyeluruh. Seorang ilmuwan tidak puas melihat ilmu dari segi pandang ilmu itu sendiri, manusia ingin melihat ilmu dari konstelasi pengetahuan yang lainnya, ahli filsafat selalu mengaitkan pemikiran filsafat dari berbagai jenis ilmu seperti kaitannya dengan politik, moral, agama, serta menghubungkan dari mana ilmu pengetahuan, hakikat ilmu pengetahuan, dan kegunaan ilmu pengetahuan.

Karakteristik kedua dari pemikiran filsafat adalah mendasar. Artinya tidak mempercayai begitu saja bahwa ilmu itu benar, mengapa ilmu dapat disebut benar, bagaimana proses penilaian, berdasarkan kreteria apa. Apa kreteria itu sendiri benar, benar itu apa. Karakteristik mendasar seperti lingkaran, pertanyaan melingkar memulai dari satu titik awal, lalu bagaimana menentukan titik awal yang benar.

Karakteristik pemikiran filsafat ketiga adalah spekulatif. Timbul suatu pertanyaan bukan spikulasi adalah suatu dasar yang tidak bisa diandakan?. Hal ini memang benar tetapi dalam menyusun sebuah lingkaran harus memulai dari sebuah titik bagaimanapun juga spekulatifnya, yang jelas dalam proses analisis dan pembuktiannya, harus ada pemisahan 
spikulasi mana yang dapat diandalkan dan mana yang tidak. Tugas filsafat adalah menetapkan dasar-dasar yang dapat diandalkan. Apa yang disebut logis, benar ? apa yang disebut alam teratur atau kacau. Apa hidup ini ada tujuannya atau absurd ? adakah hukum yang mengatur alam dan segenap kehidupan. Semua itu adalah spikulatif.

Semua pengetahuan yang sekarang ada dimulai dengan spikulasi, dari serangkaian spikulasi ini seseoramg dapat memilih buah pikiran yang dapat diandalkan yang merupakan titik awal dari penjelajahan ilmu pengetahuan. Tampa menetapkan kreteria apa yang disebut benar tidak mungkin pengetahuan berkembang di atas dasar kebenaran, tampa menetapkan apa yang disebut baik dan buruk tidak mungkin berbicara tentang moral.

Empat langkah cara berfilsafat

1. Filsafat merupakan pemikiran biasa yang dapat digugat dipertanyakan ulang, karena filsafat bukan barang yang suci. Filsafat bukan suatu prinsip-prinsip yang menghasilkan kesimpulan-kesimpulan yang kebenaranya mutlak. Filsafat bukan pemikiran yang selesai, filsafat selalu menyisahkan pertanyaan baru, sehingga pemecahan-pemecahan yang tuntas dalam filsafat tidak dimungkinkan.

2. Pemikiran filsafat mengundang seseorang untuk selalu terlibat langsung. Pemecahan persoalan filsafat mendorong seseorang agar meneruskan apa yang sudah dimulai, karena itu cobalah untuk menyanggah, ujilah kebenaran yang dikemukan oleh para filsuf.

3. Rasakan dulu pendapat orang lain dengan tampa prasngka, setelah itu bandingan dengan keyakinan diri sendiri, sebab jika keyakinan diri sendiri menjadi ukuran tidak akan menemukan mutiara yang ditawarkan orang lain.

4. Seorang filsuf tidak pernah merasa benar sendiri, karena jiwa seseorang tidak sempurna, maka pengetahuanyapun tidak sempurna. dalam filsafat tidak ada dosa bagi orang yang berbuat salah, dosa itu ada pada ketidakmaun seseorang menguji keyakinan-keyakinan bahwa kemampuan seseorang tidak bisa salah."Bukankah bila seseorang berijtihad salah mendapat satu, dan bila benar mendapat dua" jadi mengapa seseorang takut berpendapat, takut berpendapat merupakan kesalahan dan dosa.

Didalam filsafat sangat terbuka seseorang untuk mengembangkan diri, karena filsafat berpikir bebas tampa dibatasi oleh norma, dogma dan agama

\section{AGAMA}

Agama menurut Kamus Besar Bahasa Indonesia adalah sistem yang mengatur tata keimanan (kepercayaan) dan peribadatan kepada Tuhan Yang Mahakuasa serta tata kaidah yang berhubungan dengan pergaulan manusia dan manusia serta lingkungannya.Kata 
"agama" berasal dari bahasa Sansekerta āgama yang berarti "tradisi". Sedangkan kata lain untuk menyatakan konsep ini adalah religi yang berasal dari bahasa Latin religio dan berakar pada kata kerja re-ligare yang berarti "mengikat kembali". Maksudnya dengan bereligi, seseorang mengikat dirinya kepada Tuhan.

Manusia memiliki kemampuan terbatas, kesadaran dan pengakuan akan keterbatasannya menjadikan keyakinan bahwa ada sesuatu yang luar biasa diluar dirinya. Sesuatu yang luar biasa itu tentu berasal dari sumber yang luar biasa juga. Dan sumber yang luar biasa itu ada bermacam-macam sesuai dengan bahasa manusianya sendiri. Misal Allah (Tuhan)Keyakinan ini membawa manusia untuk mencari kedekatan diri kepada Tuhan dengan cara menghambakan diri, yaitu:menerima segala kepastian yang menimpa diri dan sekitarnya dan yakin berasal dari Tuhanmenaati segenap ketetapan, aturan, hukum dll yang diyakini berasal dari tuhan.Dengan demikian diperoleh keterangan yang jelas, bahwa agama itu penghambaan manusia kepada Tuhannya. Dalam pengertian agama terdapat 3 unsur, ialah manusia, penghambaandanTuhan.

Agama merupakan obat dari kesulitan dan kekhawatiran yang dihadapi manusia, sekurang-kurangnya meringankan manusia dari kesulitan. Agama merupakan pernyataan pengharapan manusia dalam dunia yang besar atau jagat raya, karena ada jalan hidup yang benar yang perlu ditemukan. Agama menjadi suatu lembaga yang bersemangat untuk memperoleh kehidupan yang baik dan merenungkannya sebagai suatu tuntutan kosmis,. Menusia menjadi penganutnya yang setia terhadap agama karena manurus keyakinannya agama telah memberikan sesuatu yang sangat berharga bagi hidupnya yang tidak mungkin dapat diuji dengan pengalaman maupun oleh akal seperti halnya menguji kebenaran sains dan filsafat karena agama lebih banyak menyangkut perasaan dan keyakinan. Agama merupakan sesuatu yang ada, karena keberadaanya itulah makanya agama dikatakan pengkajian filsafat. Landasan agama atau tauhid meurpkan landasan utama yang perlu diperhatikan dan diterapkan dalam kehidupan sehari-hari untuk keselamatan di dunia dan menjadi bekal di akhirat nanti.

\section{Filsafat dan Agama.}

Sedikkit filsafat melacurkan akal manusia kepada atheisme, tetapi ke dalaman filsafat membawa akal manusia pada agama dan filsafat bukan untuk orang awam melainkan bagi ahli pikir. Filsafat agama berpikir tentang dasar-dasar agama, tidak membahas dasar-dasar agama tertentu, melainkan dasar-dasar agama pada umumnya, berbeda dengan theologi yang 
membahas dasar-dasar agama tertentu.. Perbedaan filsafat dan agama tidak terletak pada bidangnya, akan tetapi dalam caranya penyelidikan bidang itu sendiri, filsafat berarti memikir dan agama berarti mengabdikan diri.

Filsafat merupakan pertolongan yang sangat penting pula pengaruhnya terhadap seluruh sikap dan pandangan orang, karena filsafat justru hendak memberikan dasar-dasar yang terdalam mengenai hakikat manusia dan dunia.

Ada beberapa hal yang penting dalam agama yaitu: menyakini adanya Tuhan yang menciptakan semua yang ada dilangit dan dibumi dan mengatur semua kehidupan manusia, adanya kebajikan, sifat buruk dan baik dan lain sebagainya,juga diselidi oleh filsafat karena itu merupakan atau mungkin ada secara umum kebenaran dalam agama didasarkan pada wahyu atau firman-firman Allah, sedangkan kebenaran dalam filsafat didasarkan pada pikiran belaka, agama telah menegaskan bahwa agama itu untuk orang-orang yang berakal dan berilmu pengetahuan. Maksudnya adalah dalam agama terutama gama Islam adanya aturanaturan yang ditetapkan Allah, dimana aturan Allah adalah wajib, sunat, haram, makruh dan mubah. Jadi agama dan filsafat merupakan dua hal yang saling berhubungan dan saling berkaitan, maksudnya adalah didalam agama ada aturan-aturan yang harus dipatuhi

Filsafat dan agama merupakan bidang terpenting yang menjadi soal hidup atau matinya seseorang, dan bukan persoalan yang remeh. Sejarah filsafat itu sendiri menunjukkan bahwa pada mulanya filsafat dan agama itu adalah ibarat dua serangkai yang tidak dapat dipisahkan satu dengan yang lain, hidup berdampingan dengan damai, yang demikian itu disebabkan karena filsafat itu sangat besar sekali kepentingannya bagi kemajuan akal dan pikiran manusia, sedangkan agama sangat dibutuhkan oleh jiwa dan rohani manusia sebagai pedoman dan pegangan hidup menuju ketenangan batin.

Sejarah filsuf-filsuf besar seperti Plato, Aristoteles mengakui kebesaran agama dan sangat besar jasanya dalam membuka aliran fikiran, ahli-ahli fikir agama Kristen pada masa itu hingga sekarang. Meskipun filsuf Plato dan Aristoteles adalah dua orang filsuf yang tidak beragama, tetapi mereka itu meyakinkan, merasakan dan mengakui bahwa di atas kekuasaan alam ini ada kekuasaan yang maha tinggi, itulah Tuhan Yang Maha Esa ${ }^{6}$.

Pada abad pertengahan orang-orang gereja mulai menghawatirkan agama bercampur dengan paham sesat jika kemerdekaan berpikir dilepas begitu saja, menyebabkan filsafat mengalami krisis. Tiap-tiap ahli fikir dan ilmu yang menemukan pendapat baru yang tidak

${ }^{6}$ Badawi, Filsafat Agama Penerbit CV Bintang Pelajar,Jakarta, 1979, hal 80 
sesuai dengan paham Greja dibatalkan oleh Paus dan orang yang terus mengembangkannya diancam dengan siksa, sebab di pandang murtad, ilmu pada masa itu hanya dapat dipergunakan untuk memperkuat kepercayaan agama, bukan untuk berpikir merdeka.

Ditengah keadaan zaman seperti ini, di Andalusia lahir pemikir-pemikir Islam yang sangat harum namanya di Timur maupun di Barat, di sini dapat dilihat seperti Ibnu Rusyd, Ibnu Khaldun, Ibnu Bajah, Ibnu Tufaill. Sejarah filsafat Islam menunjukkan filsuf-filsuf dan ahli pikir Islam seperti Al-Kindi, Al-Farabi, Ibnu Sina, Ibnu Rusd adalah kuat sekali mengembangkan dan menghidupkan kembali filsafat Plato dan Aristoteles, hingga saat ini tidak sedikit ahli-ahli pengetahuan barat menggali filsafat Plato dan Aristoteles dari kitabkitab karangan ahli-ahli pikir Islam $^{7}$

Menurut Immanuel Kant filsuf Jerman berkata "Terpaksalah saya melepas ilmu pengetahuan untuk mencari tempat bagi keyakinan. Pengetahuan yang dimaksud oleh Immanuel Kant adalah pengetahuan yangberdasarkan agama. Menurut Immanuel Kant filsafat dan agama itu serangkai yang tidak dapat dipisahkan untuk menjadi dasar dan pandangan hidup.

Filsafat berarti berfikir menurut tatatertib logika dengan bebas (tidak terikat pada tradisi, dogma serta agama) dan dengan sedalam-dalamnya, sehingga sampai kedasar persoalan.

Pengetahuan-pengetahuan dalam bidang keagamaan bukan hanya berdasarkan wahyu ia juga diperoleh dengan bukti-bukti historis argumen-argumen rasionalis dan pengalaman pribadi. Dasar yang terpenting bagi pengetahuan agama ialah wahyu, disini persoalannya adalah, dapatkah wahyu terjadi ?. Wahyu adalah kebenaran yang langsung disampaikan Tuhan kepada salah seorang hambanya, dengan kata lain wahyu terjadi karena adanya komunikasi antara Tuhan dan manusia. Apakah komunikasi semacam itu dapat terjadi ?. Dalam falsafah Tuhan itu disebut Mind Akal, karena Tuhan adalah akal maka manusia yang mempunyai akal tidak mustahil dapat mengadakan komunikasi dengan Tuhan sebagai akal. Dapat juga dikatakan bahwa Tuhan sebagai pencipta alam dan pengatur alam yang beredar menurut peraturan-peraturan yang rapi, ini mestilah suatu substansi atau jauwhar yang mempunyai daya pikir, dengan demikian tidaklah mustahil bahwa daya berfikir manusia dapat mempunyai hubungan komunikasi dengan daya berpikir yang terdapat dalam substansi Tuhan, kalau ini tidak mustahil, adanya wahyu tidaklah mustahil. 
Dasar utama dalam pemahaman agama adalah kepercayaan pada adanya Tuhan, tiaptiap agama berdasarkan atas kepercayaan pada sesuatu yang ghoib dan cara hidup manusia yang percaya pada agama didunia ini amat rapat hubungannya dengan kepercayaan yang ghoib.

Manusia mempercayai dasar utama dalam pemahaman agama adalah kepercayaan pada adanya Tuhan, tiap-tiap agama berdasarkan atas kepercayaan pada sesuatu yang ghoib dan cara hidup manusia yang percaya pada agama didunia ini amat rapat hubungannya dengan kepercayaanyang dimiliki oleh manusia.

Agama dan filsafat memainkan peran yang mendasar dan fundamental dalam sejarah kehidupan manusia. bukanlah pertentangan yang dibahas dalam agama dan filsafat melainkan bentuk hubungan keharmonisan dan kesesuaian antar agama dan filsafat ini sendiri.

Agama maupun filsafat pada dasarnya mempunyai kesamaan, keduanya memiliki tujuan yang sama yakni mencapai kebenaran yang sejati, tetapi terdapat pula perbedaan antara keduanya. Dalam agama ada beberapa hal yang amat penting, misalnya Tuhan, kebajikan, baik dan buruk, surga dan neraka, dan lain-lain. Hal-hal tersebut diselidiki pula oleh filsafat. Oleh karena hal-hal tersebut ada-atau paling tidak-mungkin ada.

Peran agama terhadap filsafat ialah meluruskan filsafat yang spekulatif kepada kebenaran mutlak yang ada pada agama. Sedangkan, peran filsafat terhadap agama ialah membantu keyakinan manusia terhadap kebenaran mutlak itu dengan pemikiran yang kritis dan logis.

Filsafat tidak lagi dipandang sebagai musuh agama dan salah satu faktor perusak keimanan, bahkan sebagai alat dan perantara yang bermanfaat untuk meluaskan pengetahuan dan makrifat tentang makna terdalam dan rahasia-rahasia doktrin suci agama, dengan ini niscaya menambah kualitas penghayatan dan apresiasi terhadap kebenaran ajaran agama.

Persamaan lain antara filsafat dan agama adalah masing-masing merupakan sumber nilai terutama nilai-nilai etika, perbedaannya nilai-nilai etika filsafat merupakan produk akal, sedangkan nilai-nilai agama dipercayai sebagai ditentukan oleh Tuhan.

Persoaln-persoalan yang dihadapi oleh filsafat dan agama sebagian sama, mengenai dasar hidup, tujuan hidup, etika, kebahagiaan manusia, hidup sesudah mati, pengabdian kepada Tuhan. Agama dan filsafat merupakan tuntutan kodrat dalam usaha mencapai kebenaran, kebahagiaan serta pengetahuan yang mendalam sagala sesuatu

Filsafat dan agama merupakan dua sumber pengetahuan antara keduanya tidak mungkin ada pertentangan, karena keduanya dari sumber yang satu yaitu Tuhan. Yang perlu dipahami adalah filsafat adalah ilmu yang bersifat otonomi, tidak berdasarkan atau 
berpangkalan pada agama, akan tetapi jika filsafat hendak dijadikan dasar dan pedoman hidup, perlu ditingkatkan pada lapangan agama.

Perbedaan filsafat dan agama tidak terletak pada bidangnya akan tetapi dalam caranya penyelidikan bidang itu sendiri, Filsafat berarti memikir, sedangkan agama berarti mengabdikan diri."Filsafat menuntut pengetahuan untuk memahami, sedangkan agama menuntut pengetahuan untuk beribadah. Seorang yang belajar filsafat tidak hanya mengetahui filsafat akan tetapi lebih penting dari itu ia dapat berfikir, begitu juga orang mempelajari agama, tidak akan puas dengan pengetahuan agama tetapi memerlukan membiasakan dirinya dengan hidup secara agama.

Suatu perbedaan lain antara agama dan filsafat adalah, agama banyak hubungannya dengan hati, sedangkan filsafat banyak hubungannya dengan fikiran. Seorang akhli filsafat jika berhadapan dengan penganut sesuatu aliran paham yang lain biasanya bersikap lunak, karena ia akan sanggup meninggalkan pendiriannya jika merasa dirinya salah, sebaliknya seorang yang beragama biasanya mempertahankan agamanya itu habis-habisan, karena ia sudah mengikat dirinya dan mengabdikan kepadanya.

Perbedaan yang lebih jauh antara filsafat dan agama adalah bahwa filsafat walaupun bersifat tenang dalam pekerjaanya, akan tetapi sering mengeruhkan fikiran pemeluknya, sedangkan agama walaupun memenuhi pemeluknya dengan semangat dan perasaan pengabdian diri, akan tetap mempunyai efek yang menenangkan jiwa pemeluknya.

Agama dalam bentuknya yang murni adalah kebenaran, adalah gerak yang telah sampai kepada kebenaran itu ${ }^{8}$. Kalau filsafat mencari kebenaran, maka agama telah mencapai hakikat kebenaran itu. Filsafat masih bertanya-tanya, agama telah memperoleh jawabannya, filsafat masih heran dan sangsi, ragu agama sudah percaya dan yakin.

Uraian diatas jelaslah bahwa perbedaan antara filsafat dengan filsafat agama, filsafat ilmu bergerak mencari hakikat kebenaran, sedangkan filsafat agama bergerak membukakan hakikat kebenaran. Filsafat agama berusaha dengan akal pikiran untuk membuktikan kebenaran agama sehingga dapat diterima oleh akal pikiran manusia ${ }^{9}$.Lain halnya dengan AlFarabi yang memulyakan filsafat dengan menyamakan tujuannya dengan agama, keduanya bertujuan mengetahui semua wujud, perbedaannya terletak pada dasar bertumpunya, filsafat bertumpu pada budi, memakai dalil-dalil yang disusun oleh budi dan ditujukan kepada golongan tertentu (Golongan berpikir). sedangkan agama memakai cara iqna'i dengan kiasan

\footnotetext{
${ }^{8}$ Badawi, Ibid, hal 65

${ }^{9}$ Ibid, hal 76
} 
serta gambaran yang memuaskan hati, ditujukan kepada semua orang dan bangsa ${ }^{10}$. para filsuf Islam dalam pembahasan pokok agama dan filsafat adalah satu, karena kedua-duanya memperkatakan prinsif-prinsif yang ghoib jauh dari wujud yang dihadapi. Tujuan filsafat senada dengan tujuan agama, keduanya bertujuan membina kebahagiaan melalui iman dan amal yang baik.

Tujuan filsafat dan agama adalah sama yaitu memahami dunia, tetapi tujuan kepahamanya berbeda-beda. Dalam ilmu tujuan itu hanya teori atau pengetahuan demi pengetahuan, umumnya pengetahuan diabdikan untuk tujuan-tujuan ekonomi praktis. Dalam filsafat tujuan itu ialah cinta kepada ilmu pengetahuan yang bijaksana, dengan hasil kedamaian dan kepuasan jiwa. Dalam agama tujuan itu damai keseimbangan, penyesuaian, keselamatan dirangkum dengan satu istilah Islam, salam ${ }^{11}$. Mempelajari filsafat sering mengganggu kepercayaan agama, terutama bagi yang mempunyai pandangan sempit, dalam hal ini Bacom berkata "Adalah benar bahwa sedikit filsafat meluncurkan akal manusia kepada atheisme, tetapi kedalaman filsafat membawa akal manusia kepada agama. Dan Ibnu Rusyd telah memperingatkan, filsafat itu bukan untuk orang awam tetapi bagi akhli pikir.

Sekalipun filsafat dan agama sama-sama mengabdi kepada kebenaranterdapat perbedaan besar kedudukan kebenaran itu dalam lapangan masing-masing. Pada filsafat kebenaran itu terletak diujung, ia mulai dengan kesangsian, berpikir selangkah demi selangkah dengan teratur, sadar dan konsisten untuk akhirnya diujung pemikiran sampai kepada kebenaran. Pada Agama kebenaran itu terletak dipangkal, seseorang mulai dengan kepercayaan setalah itu baru ia berpikir, dan didalam memikirkan tidak boleh lepas dari pangkal itu, kesangsian menyuburkan filsafat, apabila kesangsian itu lenyap filsafat berhenti, tetapi kesangsian dalam agama merusak, apabila seseorang sangsi pada agamanya berarti seseorang tengah meninggalkan kepercayaanya.

\section{FILSAFAT DAN AGAMA BAGI MASYARAKAT DI ERA KONTEMPORER}

Berfilsafat bukanlah merupakan pekerjaan yang setiap saat dapat saja dimulai dan yang semauanya dapat dihentikan, berfilsafat lebih merupakan suatu mentalitas berpikir suatu sikap dan penyesuaian pribadi yang dibiasakan secara perlahan-lahan dan dengan susah payah sehingga oleh karena itu menjadi milik kita secara tetap,belajar berfilsafat belajar membuka diri dan bersedia untuk itu (membuka diri), sedamgkanberagama atau

\footnotetext{
${ }^{10}$ Sidi Gazalba, Ibid, hal 97

${ }^{11}$ Ibid, 96
} 
berkeyakinan adalah suatu fitrah bagi manusia. Hal ini bertolak dari kesadaran manusia akan ketidak-berdayaan dirinya dan adanya sesuatu yang transenden yang patut diunggulkan. Agama, sebagai pegangan hidup manusia, tentu tak hanya berhenti sebagai pemikiran ideal belaka, melainkan, seiring perjalanan waktu, harus diterjemahkan dalam bingkai realitas kehidupan manusia. Agama kemudian mencari posisinya yang apresiatif terhadap realitas, namun tanpa mereduksi prinsip-prinsipnya sendiri. Pada titik inilah, pemikiran keagamaan menjadi suatu hal yang patut diperjuangkan.Dengan kondisi politik maupun ekonomi yang tidak pasti, agama sering gagal memenuhi keinginan para pemeluknya untuk memberikan kedamaian dan selalu mengutuk bentuk - bentuk kekerasan, salah satunya yaitu radikalisme.

Sementara Islam merupakan agama kedamaian yang mengajarkan sikap berdamai dan mencari perdamaian. Islam tidak pernah membenarkan praktek penggunaan kekerasan dalam menyebarkan agama, paham keagamaan serta paham politik. Tetapi memang tidak bisa dibantah bahwa dalam perjalanan sejarahnya terdapat kelompok-kelompok Islam tertentu yang menggunakan jalan kekerasan untuk mencapai tujuan politis atau mempertahankan paham keagamaannya secara kaku yang dalam bahasa peradaban global sering disebut kaum radikalisme Islam.

Gerakan radikalisme sesungguhnya bukan sebuah gerakan yang muncul begitu saja tetapi memiliki latar belakang yang sekaligus menjadi faktor pendorong munculnya gerakan radikalisme. Pemikiran radikakalissme merupakan pemikiran tuntas yang seharusnya tidak selalu diartikan melawan pemearintah, pemikiran radikalis tidak lain adalah peikiran yang sistematis mendalam sampai keakar permasalahan, keradikalan seseorang dalam menyikapi prinsip hidup philoshopinya dan pringsip hidup agamanya suatu hal yang harus diperjuangkan. Pemahaman philohopi dan pemahaman agama memang harus sinergi, seorang philoshopis harus memahami dan seorang beragama dituntut pemahaman juga harus merealisasikanya.

Sinergitas filsafat dan agama bagi kehidupan masyarakat kontemporer, dimana masyarakat kontemporer merupakan masyarakat yang mempunyai kemajuan dibidang ilmu pengetahuan yang mempunyai ruang lingkup tampa batas, dunia seakan tampa batas demarkasi yang memisahkan satu dan lainya sulit dibedakan, kemajuan ilmu pengetahuan dan tehnologi melambung jauh, karenanya filsafat sebagai philosopi kehidupan harus dipahami sebagai sebuah prinsif yang harus disenirgikan dengan agama, pemahaman agama melalui filsafat akan menemukan hakikat atau ontologi agama, sehingga dalam memahami 
dan menjalankan agama paham benar akan maksud dan tujuan dari sebauh pengamalan agama.

\section{KESIMPULAN}

Sinergitas Filsafat dan agama merupakan bidang terpenting yang menjadi soal hidup atau matinya seseorang, dan bukan persoalan yang remeh. filsafat dan agama itu adalah ibarat dua serangkai yang tidak dapat dipisahkan satu dengan yang lain, hidup berdampingan dengan damai, yang demikian itu disebabkan karena filsafat itu sangat besar sekali kepentingannya bagi kemajuan akal dan pikiran manusia, sedangkan agama sangat dibutuhkan oleh jiwa dan rohani manusia sebagai pedoman dan pegangan hidup menuju ketenangan batin.

Filsafat dan agama merupakan hal yang penting bukan hal yang remeh, filsafat dan agama menyangkut soal hidup dan matinya seseorang, filsafat sebagai landasan hidup dan agama sebagai pegangan hidup, maka sinergitasnya sangat dibutuhkan, philosofi kehidupan ini menyangkut soal prinsip kehidupan dan prinsip kehidupan merupakan suatu eksistensi kehidupan, begitu juga dengan agama sebagai tuntunan kehidupan yang membimbing arah manusia dalam menjalani kehidupan. Di era kontemporer filsafat sebagai philosopi kehidupan harus dipahami sebagai sebuah prinsif yang harus disenirgikan dengan agama, pemahaman agama melalui filsafat akan menemukan hakikat atau ontologi agama.

\section{DAFTAR PUSTAKA}

Tafsir,2013 Filsafat Umum Akal dan Hati Sejak Thales Sampai Capra, Penerbit Rosada Bandung, Androngi, 1986, Kosmologi, Filsafat Alam Semesta, Penerbit CV Bintang Pelajar Jakarta.

Baisard, Marcel, 1980, Humanisme Dalam Islam, Penerbit Bulan Bintang Jakarta.

Gazalba, Sidi, 1981, Sistematika Filsafat, Penerbit Bulan Bintang Jakarta.

Hadi, Hardono, 1994, Epistemologi, Filsafat Pengetahuan, Penerbit Kanisius Jogjakarta. Hamersma, Haryy, 1985 Fisafat Eksitensialis Karl Jaspers, Penerbit Gramedia Jakarta Hanafi, 1981, Ihtisar Sejarah Filsafat Barat, Penerbit Pustaka Al-Husna Jakarta. Huky, Wila, Capita Selecta Pengetahuan Filsafat, Penerbit Usaha Nasional Surabaya Kattsoff, Louis, 1996, Pengantar Filsafat, Penerbit Tiara Wacana, Jogjakarta. 
Karen Arstrong, Sejarah Tuhan, penerbit Mizan, Bandung, 2002

Nasution, Hasyimsyah, 1998, Filsafat Islam, Penerbit Gaya Media Pratama Jakarta.

Palmquis, Stephen, 2002, Pohon Filsafat, Penerbit Pustaka Pelajar Jogjakarta.

Salam, Burhanuddin, 1995, Pengantar Filsafat, Penerbit Bumi Angkasa Jakarta.

Suriasumantri, Juju,S, 2001, Filsafat Ilmu, SebuahPengantar Populer, Penerbit Pustaka Sinar Harapan Jakarta.

Titus, Smith, Nolan, 1984, Persoalan-persoalan Filsafat, Penerbit Bulan Bintang Jakarta.

Tafsir, Ahmad, 2013, Filsafat Umum, Penerbit PT Remaja Rosdakarya, Bandung.

\section{CURICULUM VITAE}

Nama $\quad$ : Dr. Mat Jalil. M. Hum

2. Alamat Kantor : Jl Ki Hajar Dewantara Kampus $15 \mathrm{~A}$

: Iringmulyo Kota Metro Lampung 34111

3. Telp/Faks : : (0725) 47296

4. Alamat Rumah : Il Ayani Gang Glora RW 03 RT 02 No 60

Kutoarjo GedongtaanPesawaran Lampung 35371

: Jl Riyachudu No 50 RT II Lingkungan II Depan kantor pajak kauman

metro

5. Telp/Faks : : Hp 081279539494 / 081540915066

6. E-mail : buangjalil@gmail.com

\section{PENDIDIKAN:}

1. SDN 1 Bukit Kemuning (1977)

2. MTs Darul Huda Bukit Kemuning (1980) 
3. MAN 1 Bandar Lampung (1983)

4. Sarjana Muda Ushuluddin IAIN R.Intan (1987)

5. S 1 Ushuluddin IAIN Raden Intan (1990)

6. Akta IV Universitas Lampung (1997)

7. S 2. Fakultas Filsafat UGM Jogjakarta (2004)

8. S 3 Fakultas Filsafat UGM Jogjakarta (2012)

\section{PENGALAMAN JABATAN}

- $\quad$ Katua Umum PII Jendral Emir M. Nur 1980 - 1982

- Bendahara IMM DPD Lampung 1987- 1990

- Ketua Umum MKGR 1991 - 1996

- Dekan II Fak Tarbiyah PT IMM Lampung 1988 - 1990

- Kepala Sakolah SMK Pelita Gedongtataan 1991 - 1999

- Puket II STAI Tulang Bawang 2008- 2009

- Puket I \& II STAI Tulang Bawang 2009-2011

- Ketua III PGNI 2009 - 2014

- $\quad$ Staf P2MP STAIN Jurai Siwo Metro 2008- 2011

- Ketua II FKUB Pesawaran 2011 s/d skg

- Ketua Jurusan Syari'ah STAIN Jurai siwo Metro 2011 s/d 2015

- Waka III STAIN Jurai Siwo Metro Lampung 2015 s/d 2017

- DEKAN Fakultas Ushuluddin Adab dan Da'wah 2017 s/d skg

- Ketua bidang kerukunan agama MUI Kabupaten Pesawaran 2018 s/d skg 